\title{
Systematic Review \\ Hyperthermic Intrathoracic Chemoperfusion for Malignant Pleural Mesothelioma: Systematic Review and Meta-Analysis
}

\author{
Tommi Järvinen ${ }^{1,2, *}$, Juuso Paajanen ${ }^{3} \mathbb{C}$, Ilkka Ilonen ${ }^{1,2} \mathbb{D}$ and Jari Räsänen ${ }^{1,2}$ \\ 1 Department of General Thoracic and Esophageal Surgery, Heart and Lung Center, Helsinki University \\ Hospital, 00029 Helsinki, Finland; ilkka.ilonen@hus.fi (I.I.); jari.rasanen@hus.fi (J.R.) \\ 2 Department of Surgery, Clinicum, University of Helsinki, 00029 Helsinki, Finland \\ 3 Department of Pulmonary Medicine, Heart and Lung Center, Helsinki University Hospital and University of \\ Helsinki, 00029 Helsinki, Finland; juuso.paajanen@hus.fi \\ * Correspondence: tommi.jarvinen@helsinki.fi; Tel.: +358-9-4711
}

Citation: Järvinen, T.; Paajanen, J.; Ilonen, I.; Räsänen, J. Hyperthermic Intrathoracic Chemoperfusion for Malignant Pleural Mesothelioma: Systematic Review and MetaAnalysis. Cancers 2021, 13, 3637. https://doi.org/10.3390/

cancers13143637

Academic Editor: Marco Lucchi

Received: 15 June 2021

Accepted: 12 July 2021

Published: 20 July 2021

Publisher's Note: MDPI stays neutral with regard to jurisdictional claims in published maps and institutional affiliations.

Copyright: (C) 2021 by the authors. Licensee MDPI, Basel, Switzerland. This article is an open access article distributed under the terms and conditions of the Creative Commons Attribution (CC BY) license (https:// creativecommons.org/licenses/by/ $4.0 /)$.
Simple Summary: Treatment of malignant mesothelioma with high-temperature chemotherapeutic instillation of the affected pleural space seems to be advantageous, but higher-quality studies are needed.

\begin{abstract}
Malignant pleural mesothelioma (MPM) is an aggressive malignancy of the pleural lining with exceptionally poor survival. Hyperthermic intrathoracic chemoperfusion (HITHOC) is commonly used with surgery in limited disease. However, data on its effect on survival are limited. In this systematic review and meta-analysis, we analyzed a total of 11 observational articles. HITHOC was compared to control arm that did not receive HITHOC in three studies including 762 patients. The pooled analysis of these studies revealed an SMD of 0.24 , with $95 \%$ CI of $0.06-0.41$ favoring the HITHOC group, reaching statistical significance. The survival effect of HITHOC in epithelioid MPM vs. non-epithelioid MPM was analyzed in four studies. Pooled analysis showed an SMD of 0.79 (95\% CI $=0.48-1.10)$ favoring epithelioid MPM. Based on available data, there seems to be a benefit with HITHOC in regards to overall survival in the treatment of all mesothelioma patients. Multicenter randomized controlled trials are needed to validate and standardize this treatment approach.
\end{abstract}

Keywords: malignant pleural mesothelioma; hyperthermic intrathoracic chemoperfusion

\section{Introduction}

Malignant pleural mesothelioma (MPM) is an aggressive malignancy of the pleural lining with exceptionally poor survival. Median survival from diagnosis is less than 12 months [1].

Higher than background exposure to asbestos is linked to approximately four fifths of MPM in the Western world; however, the development of MPM in all patients exposed to asbestos is very rare. This leads to a conclusion that additional factors also play a role. A DNA tumor virus, simian virus 40 (SV40), has been implicated in human MPM, as the SV40 large tumor antigen is expressed in mesothelioma cells, but not in nearby stromal cells [2]. Asbestos appears to amplify the transformative effects of SV40 on human mesothelial cells, which supports the hypothesis that SV40 and asbestos are cocarcinogens [3].

The incidence of MPM is rising globally, except in the United States, and the peak incidence is not expected to occur globally for another 5-15 years [4]. Anticipated peaks in Europe and Australia are not predicted to occur for another 5-10 years. In Japan and other non-Western countries, the peak is expected to be delayed compared to Western countries, as widespread use of asbestos in construction occurred later [3].

In cases of limited disease, extensive tumor extraction can be achieved with either extrapleural pneumonectomy (EPP) or extended pleurectomy/decortication (P/D) operations, techniques of which have been previously described [5]. The aim of radical surgery 
is to achieve macroscopic complete resection (MCR). In addition to surgery, adjuvant therapies, such as chemoradiation, intrapleural chemotherapy, and photodynamic therapy, are used [6-8]. Recurrence after only surgical treatment is common and, thus, multimodality treatment including surgery is the mainstay of curative intent treatment, and, in some countries, surgery is not recommended for MPM [9].

Intraoperative intrapleural injection of cytotoxic drugs, such as cisplatin, doxorubicin, gemcitabine, or epirubicin, with hyperthermic perfusion at the time of surgery, i.e., hyperthermic intrathoracic chemotherapy (HITHOC), is a widely used method of multimodality treatment for MPM to optimize local disease control $[7,9,10]$. A well-described technique of HITHOC is as follows: first, an extended right or left thoracotomy is performed and usually accompanied by a resection of the seventh rib. Then, before the administration of intrapleural chemotherapy, surgical thoracic cytoreduction, usually either P/D or EPP, is performed in an attempt to remove all macroscopic evidence of malignant disease. The pleurectomy involves all parietal and visceral pleural surfaces, including the diaphragm and fissures [11]. This can be accompanied by resection of pericardium and/or diaphragm. In EPP, the ipsilateral lung is removed with the pleural cavity [5]. Some surgeons use diaphragm- and pericardium-sparing partial pleurectomy as the cytoreductive operation of choice $[12,13]$. Hemostasis and irrigation are then performed and, typically, a partial closure of skin at the thoracotomy site and elevation of skin flaps are performed to form a reservoir. Then, a catheter is inserted through the thoracotomy for infusion of the chemotherapy solution, and a drainage thoracostomy ( 28 French) tube is inserted at the level of the diaphragm and aimed to the apex of the thoracic cavity. A heated chemotherapeutic agent is circulated by a hyperthermia pump. The ipsilateral lung is maintained at a partially collapsed state during this infusion [11]. Potential benefits of HITHOC include enhanced local cytotoxic effects on tumor cells, with limited systemic side effects $[14,15]$. Despite its wide usage and its well-established counterpart of hyperthermic intraperitoneal chemotherapy (HIPEC) in the treatment of peritoneal carcinomatosis and pseudomyxoma peritonei, relatively little evidence exists on the benefits of HITHOC in the treatment of MPM [16].

The aim of this systematic review and meta-analysis was to elucidate the effect of HITHOC on the survival of patients with MPM, as well as to compare the effect size between the various histologic subtypes (epithelioid, biphasic, and sarcomatoid). We also analyzed the rate of reported complications. To our knowledge, this is the first metaanalysis that analyzes the role of HITHOC exclusively to mesothelioma.

\section{Methods}

\subsection{Design}

This is a systematic literature review and meta-analysis that followed a predetermined study protocol according to Preferred Reporting Items for Systematic Reviews and MetaAnalyses (PRISMA) guidelines for systematic reviews and meta-analyses.

\subsection{Literature Search Strategy}

A systematic literature search until January 2021 from multiple databases (Embase, Medline, and Cochrane library) was conducted by the first author (T.J.). The search was performed by combining medical subject headings (MeSH) and related free-text search terms with Boolean operators "AND" or "OR". The search line used was "Mesotheliom* AND (Hypertherm* AND (intrathorac* OR intrapleur* OR Intracav*) AND Chemother*)".

\subsection{Study Selection}

The inclusion criteria were as follows: (1) Study including only malignant pleural mesothelioma patients; (2) Study investigating use of hyperthermic intrathoracic/intrapleural chemotherapy; (3) Study reported endpoint of overall survival; (4) Study was done in adults ( $>18$ years of age). Exclusion criteria were: (1) English translation of the manuscript not available. 


\subsection{Data Extraction}

Titles and abstracts were scrutinized by the first author (Tommi Järvinen) and duplicates were identified simultaneously. Full texts of potential studies were analyzed by 2 authors (Tommi Järvinen and Ilkka Ilonen). Summary data were extracted from included studies. Extracted data included publication year, sample size, histology, HITHOC agents used, HITHOC temperatures used, length of HITHOC infusion, technique of HITHOC, possible cytoprotective and other adjuncts to HITHOC, operative technique, staging of the tumor, follow-up, full report of complications and length of hospital stay, and overall survival. Authors were contacted directly in order to receive missing data if the study was otherwise eligible for inclusion.

\subsection{Informed Consent}

As a meta-analysis that does not include or process individual patient level data, no informed consent, as per Helsinki University Institutional Review Board guidelines, was needed.

\subsection{Outcome Measures and Statistical Analysis}

The effect size on overall survival was measured using Hedge's $g$, which was calculated using median overall survival, number of cases in each group, and $p$ value.

Meta-analysis of data was conducted using a random effects model due to high heterogeneity. Publication bias was assessed by funnel plots (plots of effect estimates against sample size) to detect outliers or asymmetry. Funnel plot asymmetry was analyzed visually and by Egger test for small-study effects and publication bias. The statistical significance for Egger test was set at $p<0.10$, as originally described by Egger et al. [17]. Forest plots, i.e., graphical display of estimated odds ratios and $95 \%$ confidence intervals, and summary statistics were used to elucidate the results of the studies.

The I2 test was used to evaluate statistical heterogeneity, also known as the outcome variability, in excess of what would be expected due to measurement error alone of the included studies, with levels of heterogeneity defined as not important $\left(\mathrm{I}^{2}=0-25 \%\right)$, moderate $\left(\mathrm{I}^{2}=25-50 \%\right)$, substantial $\left(\mathrm{I}^{2}=50-75 \%\right)$, or considerable $\left(\mathrm{I}^{2}=75-100 \%\right)$.

Significance level used was $p<0.05$. Statistical analysis was performed with R (R Core Team (2020). R: A language and environment for statistical computing. R Foundation for Statistical Computing, Vienna, Austria. URL https:/ /www.R-project.org/ acessed on 1 January 2020)

\section{Results}

A total of 63 original manuscripts were identified by our search strategy. Figure 1 outlines the inclusion process, as per Preferred Reporting Items for Systematic Reviews and Meta-Analyses (PRISMA) guidelines.

A review of abstracts and titles yielded 24 manuscripts for further evaluation, of which 11 were included in the systematic review. A total of 13 studies were excluded after full text review, as seven studies included other malignancies than MPM (such as thymoma, lung cancer, and mesenchymal malignancies), three studies did not report the prespecified end points, two studies had no English translations available, one study did not use HITHOC in any of the patients, and, lastly, one study for being a review article. Six studies originated from the USA [7,10,18-21], three from Italy [12,13,22], one from the Netherlands [23], and one from Germany [24]. All of the included studies were observational in nature, and no randomized data regarding this subject are published. These studies and the number of treated patients, their surgical approaches, and group comparisons that could be extracted from the articles are outlined in Table 1. The details of HITHOC treatments are shown in Table 2. 

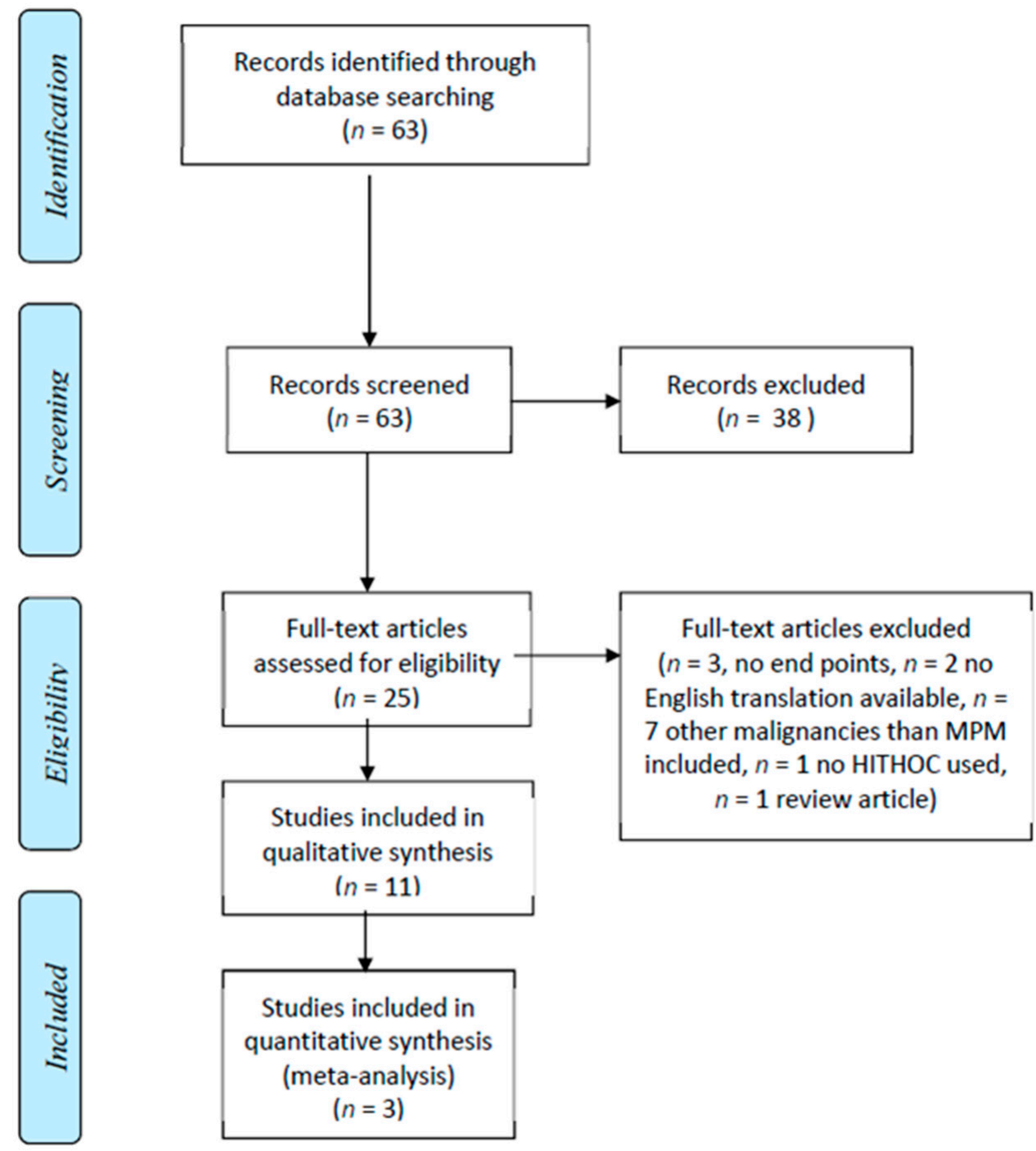

Figure 1. Flow chart of database search and literature selection, as per Preferred Reporting Items for Systematic Reviews and Meta-Analyses (PRISMA) guidelines.

Table 1. Studies included in the systematic review.

\begin{tabular}{|c|c|c|c|c|c|}
\hline Author & Year & Country & $N$ & Treatment & Groups Compared \\
\hline Richards et al. [18] & 2006 & USA & 44 & $\mathrm{P} / \mathrm{D}^{*}$ and $\mathrm{HITHOC}^{\dagger}$ & Histologic subtypes \\
\hline van Sandick et al. [23] & 2008 & Netherlands & 35 & $\begin{array}{l}\mathrm{EPP} \ddagger \text { or P/D }{ }^{*} \text { with HITHOC }{ }^{\dagger} \\
\text { or EPP with hemithoracic RT } \S\end{array}$ & HITHOC $^{\dagger}$ vs. no-HITHOC ${ }^{\dagger}$ \\
\hline Zellos et al. [10] & 2009 & USA & 29 & EPP $\ddagger$ with HITHOC ${ }^{\dagger}$ & $\begin{array}{c}\text { Histologic subtypes, tumor } \\
\text { stage }\end{array}$ \\
\hline Tilleman et al. [7] & 2009 & USA & 121 & EPP $\ddagger$ with $\mathrm{HITHOC}^{\dagger}$ & $\begin{array}{c}\text { HITHOC } \\
\text { histologic substypes, tumor } \\
\text { stage }\end{array}$ \\
\hline Sugarbaker et al. [20] & 2013 & USA & 103 & $\begin{array}{c}\text { EPP } \ddagger \text { or } \mathrm{P} / \mathrm{D}^{*} \text { with HITHOC }{ }^{\dagger} \\
\text { with or without HITHOC }\end{array}$ & HITHOC $^{\dagger}$ vs. no-HITHOC ${ }^{\dagger}$ \\
\hline Migliore et al. [22] & 2015 & Italy & 6 & $\mathrm{P} / \mathrm{D}^{*}$ and HITHOC ${ }^{+}$ & $\mathrm{N} / \mathrm{a}$ \\
\hline Bertoglio et al. [13] & 2017 & Italy & 26 & Partial pleurectomy & Tumor stage \\
\hline Burt et al. [21] & 2018 & USA & 104 & $\mathrm{EPP} \ddagger$ or $\mathrm{P} / \mathrm{D}^{*}$ with HITHOC ${ }^{\dagger}$ & $\mathrm{EPP} \ddagger$ vs P/D* \\
\hline Ambrogi et al. [12] & 2018 & Italy & 49 & Partial pleurectomy & Histologic subtypes \\
\hline Klotz et al. [24] & 2019 & Germany & 71 & $\mathrm{P} / \mathrm{D}^{*}$ with HITHOC ${ }^{+}$ & $\begin{array}{l}\text { Histologic subtypes, resection } \\
\text { completeness }\end{array}$ \\
\hline Hod et al. [19] & 2021 & USA & 503 & $\begin{array}{c}\mathrm{EPP} \ddagger \text { or } \mathrm{P} / \mathrm{D}^{*} \text { with or without } \\
\mathrm{HITHOC}^{+}\end{array}$ & Acute kidney injury stages \\
\hline
\end{tabular}

* Pleurectomy and/or decortication; ${ }^{\dagger}$ hyperthermic intrapleural chemotherapy; ${ }^{\ddagger}$ extrapleural pneumonectomy; ${ }^{\S}$ radiotherapy. 
Table 2. Details of hyperthermic intrathoracic chemotherapies used.

\begin{tabular}{|c|c|c|c|c|c|}
\hline Author & Agents & Dose & Temperature & Duration (min) & Adjuncts \\
\hline Richards et al. [18] & cisplatin & $\begin{array}{l}\text { Escalation from } 50 \\
\mathrm{mg} / \mathrm{m}^{2} \text { to } 250 \mathrm{mg} / \mathrm{m}^{2}\end{array}$ & $42{ }^{\circ} \mathrm{C}$ & 60 & $\begin{array}{c}\text { Intravenous } \\
\text { sodium thiosulfate }\end{array}$ \\
\hline van Sandick et al. [23] & $\begin{array}{c}\text { cisplatin, } \\
\text { adriamycin }\end{array}$ & $80 \mathrm{mg} / \mathrm{m}^{2}, 20 \mathrm{mg} / \mathrm{m}^{2}$ & $40-41^{\circ} \mathrm{C}$ & 90 & \\
\hline Zellos et al. [10] & cisplatin & $910 \mathrm{mg} / \mathrm{m}^{2}$ & $42{ }^{\circ} \mathrm{C}$ & 60 & $\begin{array}{l}\text { Intravenous } \\
\text { amifostine }\end{array}$ \\
\hline Tilleman et al. [7] & cisplatin & $225 \mathrm{mg} / \mathrm{m}^{2}$ & $42{ }^{\circ} \mathrm{C}$ & 60 & $\begin{array}{l}\text { Intravenous } \\
\text { sodium thiosulfate } \\
\text { and amifostine } \\
\text { Intravenous }\end{array}$ \\
\hline Sugarbaker et al. [20] & cisplatin & $175-225 \mathrm{mg} / \mathrm{m}^{2}$ & $42{ }^{\circ} \mathrm{C}$ & 60 & $\begin{array}{l}\text { sodium thiosulfate } \\
\text { and amifostine }\end{array}$ \\
\hline Migliore et al. [22] & cisplatin & $120 \mathrm{mg} / \mathrm{m}^{2}$ & $42.5^{\circ} \mathrm{C}$ & 60 & \\
\hline Bertoglio et al. [13] & $\begin{array}{c}\text { cisplatin, } \\
\text { doxorubicin }\end{array}$ & $80 \mathrm{mg} / \mathrm{m}^{2}, 25 \mathrm{mg} / \mathrm{m}^{2}$ & $42.5^{\circ} \mathrm{C}$ & 60 & \\
\hline Burt et al. [21] & cisplatin & $175-225 \mathrm{mg} / \mathrm{m}^{2}$ & $42{ }^{\circ} \mathrm{C}$ & 60 & $\begin{array}{l}\text { Intravenous } \\
\text { sodium thiosulfate } \\
\text { and amifostine }\end{array}$ \\
\hline Ambrogi et al. [12] & $\begin{array}{l}\text { cisplatin, } \\
\text { epirubicin }\end{array}$ & $80 \mathrm{mg} / \mathrm{m}^{2}, 25 \mathrm{mg} / \mathrm{m}^{2}$ & $42.5^{\circ} \mathrm{C}$ & 60 & \\
\hline Klotz et al. [24] & $\begin{array}{c}\text { cisplatin, } \\
\text { doxorubicin }\end{array}$ & $200 \mathrm{mg}, 100 \mathrm{mg}$ & $42{ }^{\circ} \mathrm{C}$ & 90 & \\
\hline Hod et al. [19] & $\begin{array}{c}\text { cisplatin, } \\
\text { gemcitabine }\end{array}$ & $\begin{array}{c}175-225 \mathrm{mg} / \mathrm{m}^{2} \\
900 \mathrm{mg} / \mathrm{m}^{2}\end{array}$ & $42{ }^{\circ} \mathrm{C}$ & 60 & $\begin{array}{l}\text { Intravenous } \\
\text { sodium thiosulfate } \\
\text { and amifostine }\end{array}$ \\
\hline
\end{tabular}

HITHOC was compared to control arm that did not receive HITHOC in four studies, including 762 patients $[7,19,20,23]$. Van Sandick et al. [23] compared EPP or P/D with HITHOC to EPP with hemithoracic radiation, their intrapleural chemotherapy regimen was cisplatin (fixed dose of $80 \mathrm{mg} / \mathrm{m}^{2}$ ) and adriamycin (dose starting at $20 \mathrm{mg} / \mathrm{m}^{2}$, with increments of $5 \mathrm{mg} / \mathrm{m}^{2}$ per dose step) at $40-41^{\circ} \mathrm{C}$ for $90 \mathrm{~min}$. Tilleman et al. [7] performed EPP and used a $1 \mathrm{~h}$ lavage of the chest and abdomen with cisplatin $\left(225 \mathrm{mg} / \mathrm{m}^{2}\right)$ at $42{ }^{\circ} \mathrm{C}$, with intravenous sodium thiosulfate, with or without amifostine as a cytoprotective agent. Sugarbaker et al. [20] compared patients who had undergone either EPP or P/D and been given neoadjuvant/adjuvant treatment (control group) or HITHOC (cisplatin 175 to $225 \mathrm{mg} / \mathrm{m}^{2}$ for a $1 \mathrm{~h}$ lavage at $42{ }^{\circ} \mathrm{C}$, with sodium thiosulfate rescue and/or amifostine protection). This study also included only MPM with epithelioid histology at needle biopsy; however, 16 of the patients were found to have biphasic histology in the final pathology report [20]. Hod et al. [19] compared HITHOC to no HITHOC in regards to AKI. The authors were contacted in order to receive the data needed for inclusion in the meta-analysis. Their HITHOC regimen used cisplatin $\left(175-225 \mathrm{mg} / \mathrm{m}^{2}\right)$ and gemcitabine $\left(900 \mathrm{mg} / \mathrm{m}^{2}\right)$ with amifostine and sodium thiosulfate protection. The pooled analysis of these studies revealed a standardized mean difference (SMD) of 0.24 , with $95 \%$ CI of 0.06-0.41 favoring the HITHOC group. Figure 2 shows the associated forest plot. There was marked study heterogeneity $\mathrm{I}^{2}=66 \%, p=0.03$. 
Author

Van Sandick et al 2008

Tilleman et al 2009

Sugarbaker et al 2013

Hod et al 2021

Fixed effect model

Prediction interval

Heterogeneity: $I^{2}=66 \%, \tau^{2}=0.0809, p=0.03$
Hedges's $g \quad 95 \% \mathrm{Cl} \quad \mathrm{SE}$

Standardised Mean Difference

$-0.58[-1.27 ; 0.10] 0.3489$

$0.53[0.11 ; 0.95] 0.2157$

$0.48[0.06 ; 0.91] 0.2175$

$0.18[-0.05 ; 0.40] 0.1160$

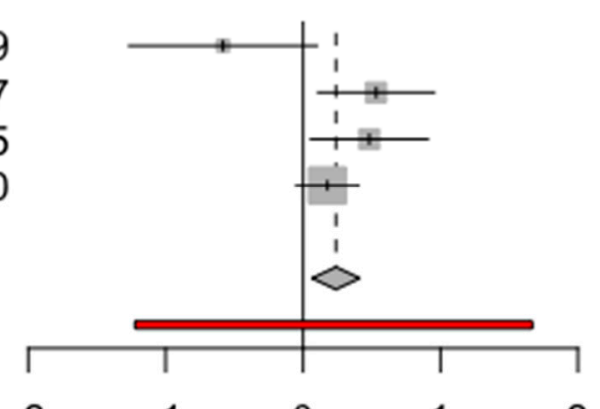

$-2 \quad-1$

Favoring control

Favoring HITHOC

Figure 2. Forest plot of HITHOC vs. no HITOC.

The survival effect of HITHOC in epithelioid MPM vs. non-epithelioid MPM was analyzed in four studies [7,10,12,18]. Richards et al. [18] studied 24 patients with epithelioid type and 20 with non-epithelioid. Ambrogi et al. [12] reported 43 epithelioid and 6 nonepithelioid tumors. Zellos et al. [10] included 24 epithelioid types and 5 non-epithelioid types. Tilleman et al. [7] had 53 patients with epithelioid, 36 with biphasic, and 5 with sarcomatoid histology. All studies reported an improved survival in epithelioid MPM compared to non-epithelioid MPM. Pooled analysis showed an SMD of 0.79 (95\% CI = 0.48-1.10), favoring epithelioid MPM, as shown in Figure 3. As per Cohen et al. [25], an SMD of 0.79 can be interpreted as a borderline "large" effect. Heterogeneity was negligible $\mathrm{I}^{2}=0 \%$, $p=0.42$.

Author

Ambrogi et al. 2017

Zellos et al. 2008

Tilleman et al. 2009

Richards et al. 2006

Fixed effect model

Prediction interval

Heterogeneity: $I^{2}=0 \%, \tau^{2}=0, p=0.42$

\section{$95 \% \mathrm{Cl} \quad \mathrm{SE}$ Difference}

$1.02[0.14 ; 1.89] 0.4481$

$1.42[0.39 ; 2.46] 0.5279$

$0.58[0.16 ; 1.00] 0.2153$

$0.91[0.28 ; 1.53] 0.3184$

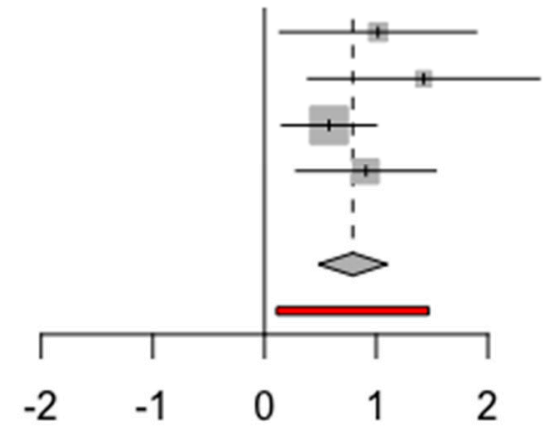

Favoring epithelial

Figure 3. Forest plot of epithelial histology vs. nonepithelial histology.

\section{Complications Related to HITHOC}

Of the 11 studies included in this systematic review and meta-analysis, only 1 study did not report any data related to complications [20]. However, the reporting and definition of complications is very heterogeneous between the studies, and two studies reported only the total amount of complications and one study only the incidence of AKI [13,19]. Reported rates of some major complications related to the treatments given are shown in Table 3. The rate of complications varies between 16.7 and $62.9 \%$. Among the most common complications are cardiac complications (7.7-34.1\%), such as AF, myocardial infarction, pulmonary embolism, pericarditis, and cardiac dysfunction. Acute kidney injury, mostly related to HITHOC, varied greatly between studies, with the highest incidence with 
Zellos et al. [10] (75.7\%) and lowest with Tilleman et al. [7] (3.3\%). Reoperation rates also had much variance, as the lowest rate reported was $2.0 \%$ with Ambrogi et al. [12] and the highest incidence was $40 \%$ with van Sandick et al. [23]. Median hospital stay varied between 8 and 26 days.

Table 3. Complications reported in studies.

\begin{tabular}{|c|c|c|c|c|c|c|c|c|c|}
\hline Author & $\underset{\substack{\text { Any } \\
\text { Complication }}}{ }$ & $\underset{(\%)}{\text { Pneumonia }}$ & $\begin{array}{c}\text { Pneumo- } \\
\text { thorax (\%) }\end{array}$ & $\underset{(\%)}{\text { Empyema }}$ & $\underset{(\%)}{\operatorname{ARDS} *}$ & $\underset{(\%)}{\mathrm{AKI}}$ & $\begin{array}{c}\text { Cardiac } \\
\text { Complication } \\
\Omega(\%)\end{array}$ & $\begin{array}{c}\text { Reoperation } \\
(\%)\end{array}$ & $\begin{array}{c}\text { Median } \\
\text { Hospital } \\
\text { Stay (Days) }\end{array}$ \\
\hline \multirow{2}{*}{$\begin{array}{c}\text { Richards et al. [18] } \\
\text { van Sandick et al. } \\
{[23]}\end{array}$} & $\mathrm{N} / \mathrm{A}$ & 9.1 & $\mathrm{~N} / \mathrm{a}$ & $\mathrm{N} / \mathrm{A}$ & 11.4 & 43.9 & 34.1 & 4.5 & 11 \\
\hline & 62.9 & $\mathrm{~N} / \mathrm{A}$ & $\mathrm{N} / \mathrm{a}$ & 8.6 & $\mathrm{~N} / \mathrm{A}$ & $\mathrm{N} / \mathrm{A}$ & 31.4 & 40.0 & 15 \\
\hline \multirow{2}{*}{$\begin{array}{c}\text { Tilleman et al. [7] } \\
\text { Sugarbaker et al. } \\
\text { [20] }\end{array}$} & $\begin{array}{l}\mathrm{N} / \mathrm{A} \\
48.9\end{array}$ & $\begin{array}{l}10.3 \\
3.3\end{array}$ & $\begin{array}{l}\mathrm{N} / \mathrm{a} \\
\mathrm{N} / \mathrm{a}\end{array}$ & $\begin{array}{l}10.3 \\
2.2\end{array}$ & $\begin{array}{l}28.6 \\
6.5\end{array}$ & $\begin{array}{l}75.7 \\
3.3\end{array}$ & $\begin{array}{l}\mathrm{N} / \mathrm{A} \\
29.3\end{array}$ & $\begin{array}{r}20.7 \\
\text { N/A }\end{array}$ & $\begin{array}{l}15 \\
12\end{array}$ \\
\hline & $\mathrm{N} / \mathrm{A}$ & $\mathrm{N} / \mathrm{A}$ & $\mathrm{N} / \mathrm{a}$ & $\mathrm{N} / \mathrm{A}$ & $\mathrm{N} / \mathrm{A}$ & $\mathrm{N} / \mathrm{A}$ & $\mathrm{N} / \mathrm{A}$ & $\mathrm{N} / \mathrm{A}$ & 12 \\
\hline Migliore et al. [22] & 16.7 & $\mathrm{~N} / \mathrm{A}$ & $\mathrm{N} / \mathrm{a}$ & $\mathrm{N} / \mathrm{A}$ & $\mathrm{N} / \mathrm{A}$ & $\mathrm{N} / \mathrm{A}$ & $\mathrm{N} / \mathrm{A}$ & $\mathrm{N} / \mathrm{A}$ & $\mathrm{N} / \mathrm{A}$ \\
\hline Bertoglio et al. [13] & 50.0 & N/A & $\mathrm{N} / \mathrm{a}$ & $\mathrm{N} / \mathrm{A}$ & $\mathrm{N} / \mathrm{A}$ & $\mathrm{N} / \mathrm{A}$ & $\mathrm{N} / \mathrm{A}$ & $\mathrm{N} / \mathrm{A}$ & $\mathrm{N} / \mathrm{A}$ \\
\hline Burt et al. [21] & 57.7 & $\mathrm{~N} / \mathrm{A}$ & 1.9 & 1.0 & 3.8 & 4.8 & 7.7 & $\mathrm{~N} / \mathrm{A}$ & $\mathrm{N} / \mathrm{A}$ \\
\hline Ambrogi et al. [12] & 46.9 & $\mathrm{~N} / \mathrm{A}$ & $\mathrm{N} / \mathrm{a}$ & 2.0 & $\mathrm{~N} / \mathrm{A}$ & N/A & $\mathrm{N} / \mathrm{A}$ & 2.0 & 8 \\
\hline Klotz et al. [24] & 57.7 & 16.9 & 28.2 & $\mathrm{~N} / \mathrm{A}$ & $\mathrm{N} / \mathrm{A}$ & $\mathrm{N} / \mathrm{A}$ & 23.9 & 14.1 & 26 \\
\hline Hod et al. [19] & $\mathrm{N} / \mathrm{A}$ & $\mathrm{N} / \mathrm{A}$ & $\mathrm{N} / \mathrm{A}$ & $\mathrm{N} / \mathrm{A}$ & $\mathrm{N} / \mathrm{A}$ & 48.3 & $\mathrm{~N} / \mathrm{A}$ & $\mathrm{N} / \mathrm{A}$ & $\mathrm{N} / \mathrm{A}$ \\
\hline
\end{tabular}

${ }^{*}$ Adult respiratory distress syndrome; ${ }^{\bullet}$ acute kidney injury; ${ }^{\Omega}$ atrial fibrillation, heart failure, myocardial infarction, pericarditis, pulmonary embolism; N/A-not available.

\section{Discussion}

A statistically significant signal of prolonged survival with HITHOC was reached in this meta-analysis. Epithelioid histologic subtype seems to have a better prognosis when treated with HITHOC.

Currently, surgery, namely EPP or P/D, is the main treatment for limited disease MPM. Some studies in this review used partial pleurectomy (pericardium, lung, and diaphragm sparing) as the surgical treatment of choice $[12,13]$. Other therapies, such as radiotherapy, chemotherapy, and chemoradiation, have been combined with surgery as preoperative, perioperative or postoperative adjuncts to enhance the therapeutic effect of surgery, as well as to control the high recurrence rate of MPM after only surgery.

Several peri- or intraoperative intracavitary therapies have been proposed in order to improve loco-regional effect of surgery. The rationale for intrathoracic therapies is to spread cytotoxic agents on the microscopic tumor surface, where a direct and more efficient effect can be achieved, limiting the systemic adverse effects [13]. In addition to HITHOC, antiseptic povidone [26], photodynamic therapy [27], and immunotherapies [28] have been used. However, even if some of the preliminary findings are encouraging, results are still based largely on low-quality retrospective data, and intracavitary treatments are recommended to be used within a clinical trial [29].

The most popular cytotoxic drugs used for HITHOC were cisplatin followed by doxorubicin and mitomycin $\mathrm{C}$, and $41-43^{\circ} \mathrm{C}$ was most commonly used in HITHOC. The standard time for infusion was 60-90 min across the studies. Intrathoracic instillation of chemotherapeutic agents allows for a much higher concentration of the drug in the pleural cavity when compared to systemic chemotherapy, potentially improving the cytotoxic effect to the tumor cells and minimizing systemic adverse effects. The potential benefits of intracavitary chemotherapeutic infusion are numerous, and include increased penetration of chemotherapy into tumor, delayed cavitary clearance of chemotherapy after direct instillation, and increased cytotoxicity with selected chemotherapy agents [30,31]. In theory, the efficacy of chemotherapy is improved by hyperthermia, as local drug absorption increases and chemotherapeutic drug action enhances [30]. The biological mechanism behind the effect of hyperthermia is thought to be protein denaturation of the cancer cells at a temperature of $44^{\circ} \mathrm{C}$ for $1 \mathrm{~h}$, while nonmalignant tissues are relatively unharmed at this temperature [31]. This protein denaturation of cancer cells, in turn, results in a rise in the rate of tumor cell apoptosis. This is mainly conveyed through alteration in the DNA synthesis of the cell, cell membrane cytoskeleton, and membrane permeability [14]. Its benefit in the treatment of mucinous appendiceal neoplasms, colorectal cancer peritoneal metas- 
tases, gastric cancer carcinomatosis, and ovarian cancer is rather well established [32-36]. However, intrapleural chemoperfusion has a significant risk of comorbidity, especially the risk of acute kidney injury (AKI), and there seems to be a dose-dependent risk [19]. The pharmacokinetics of intrathoracic instillation of mitomycin $C$ and doxorubicin differ from intrapleural instillation, as the intrathoracic absorption efficiency seems to be about half of that of intrapleural absorption, even when comparable and consistently high concentrations are maintained [11]. Unfortunately, no randomized controlled trials on the use of hyperthermic intracavitary chemotherapy exist in pleural malignancies. Thus, this meta-analysis highlights the importance for such, as the results are nonuniform and there is no consensus for this matter.

A previous systematic review by Zhao et al. [37] on this subject found a statistically significant effect favoring HITHOC in the treatment of pleural malignancies. This metaanalysis included five studies in its qualitative synthesis. One of the studies included treated patients with other pleural malignancies than MPM, such as thymoma and lung cancer, and, thus, by our inclusion criteria, this study could not be included in the summary statistics [38]. Zhao et al. [37] also included a study that did not use HITHOC, but hyperthermic pleural lavage with povidone-iodine, and, thus, was excluded from our analysis [26]. As a result, only three studies were included in the analysis. However, the authors of a recent study by Hod et al. [19] were gracious enough to provide us with the data needed in order to include their results in our meta-synthesis [19]. Of the included studies, Tilleman et al. [7], Sugarbaker et al. [20], and Hod et al. [19] reported improved survival with surgery with HITHOC vs. surgery without HITHOC. Van Sandick et al. [23] reported markedly worse survival with HITHOC and either EPP or P/D without radiation therapy (RT) compared to EPP, no HITHOC, and hemithoracic RT. Thus, in this study, the effects of HITHOC on survival are greatly confounded by the difference of other treatment modalities between the study groups [23].

We also tried to analyze the importance of histologic subtype, epithelioid, sarcomatoid, or biphasic being the main subtypes, of MPM for HITHOC therapy. Epithelioid subtype of MPM has been described previously to have a much better overall prognosis than sarcomatoid or biphasic MPM [39]. Although a statistically significant benefit of HITHOC in the treatment of all patients could not be established in this meta-analysis, the effect on only epithelioid subtype remains unknown, as none of the included studies that compared HITHOC to no HITHOC reported survival statistics of only epitheloid subtype $[7,20,23]$. However, our analysis confirms previous findings that histologic subtype affects survival on surgically treated patients, with epithelioid subtype having clearly better OS than sarcomatoid and biphasic subtypes [40].

The rate of complications following surgery and HITHOC seem to differ a great deal between the studies, as shown in Table 2. This is most likely a reporting issue, as reported complications were not uniform between the studies, and some studies reported no complications or only total amount of complications. The definition and diagnosis of complications most likely is heterogeneous between the studies, but for the exception of Hod et al. [19] with AKI, no studies went into detail on definition of their complications. Nevertheless, the overall rate of complications and morbidity seems to be quite high, ranging from 16.7 to $62.9 \%$, and all but one study reporting approximately half of patients suffering from complications, as shown in Table 2. While some of the complications reported, such as bronchopleural fistulae, diaphragm rupture, and laryngeal nerve dysfunction, are likely attributable to the surgical treatment, such as EPP or P/D, given, it is mostly not possible to deduce from the included studies whether the complications are related to the surgical procedure or administration of HITHOC or both. Indeed, complications from HITHOC per se have been postulated to be quite low, as Liu et al. [41] recently reported incidence of side effects of HITHOC to be $2.0 \%$ in 1510 treatments on 315 patients with malignant pleural effusion. The HITHOC in this study was performed under local anesthesia and puncture technique, at bedside, with no associated surgical intervention [41]; 30-day mortality after bedside HITHOC was zero, and most common complications were related to the pleural 
puncture (pneumothorax, pain at puncture site) [41]. Judging by these findings, HITHOC itself is relatively safe and well tolerated, and, in this study by Liu et al. [41], this method of bedside HITHOC was superior to conventional intraoperative HITHOC.

There are numerous limitations to this meta-analysis. No RCTs comparing HITHOC and surgery to other multimodality therapies, or even surgery alone, exist, so the metaanalysis synthesizes only retrospective data. For this reason, it is subject to the same biases as the studies included and has a significant risk of amplifying them. Moreover, only three of the eleven studies could be enrolled in the qualitative synthesis of overall survival between HITHOC vs. no HITHOC, with a limited number of patients, and only four of the studies could be included in the qualitative synthesis of overall survival between histologic subtypes. The studies included in this meta-analysis suffer from heterogeneity, as the studies and even the groups within the studies have differences in surgeries used, other treatment modalities (such as RT) used, chemotherapeutic agents used in HITHOC, HITHOC temperatures, and HITHOC durations, as shown in Table $1[7,20,23]$. However, due to low volume of the cases and declining incidence in the future, there are no prospective trials to address these study questions on the horizon.

Based on available data, we were not able draw any definitive conclusion of the benefit of HTHOC in treatment of all mesothelioma patients, although there seems to be a statistically significant effect in favor of HITHOC. It is obvious that patients with epithelioid subtype have a better prognosis after HITHOC treatment than with other subtypes, but whether this difference is of significance in overall prognosis remains unclear because of the poor quality of accessible data. Multicenter randomized controlled trials are needed to validate and standardize this treatment approach.

\section{Conclusions}

There is a signal of benefit with HITHOC in MPM patients, but higher quality data are needed to make a definitive conclusion.

Author Contributions: Author Contributions: Conceptualization, T.J., I.I. and J.R.; Methodology, T.J., I.I. and J.R.; Software, T.J.; Validation, T.J., I.I., J.P. and J.R.; Formal Analysis, T.J.; Investigation, T.J., I.I., J.P. and J.R.; Resources, T.J.; Data Curation, T.J.; Writing—Original Draft Preparation, T.J., I.I., J.P. and J.R.; Writing-Review \& Editing, All Authors; Visualization, T.J., I.I., J.P. and J.R.; Supervision, I.I. and J.R.; Project Administration, I.I. and J.R. All authors have read and agreed to the published version of the manuscript.

Funding: No external funding was received for this study.

Institutional Review Board Statement: Ethical review and approval were waived for this study, due to the study not involving any patient level data.

Informed Consent Statement: Informed Consent Statement was waived for this study, due to the study not involving any patient level data.

Data Availability Statement: The R code used for data analysis can be requested by contacting the corresponding author; no other original data was involved in this study.

Acknowledgments: The authors would like to acknowledge Suraj Sarvode Mothi and Sushrut S. Waikar for providing in-depth data regarding their publication [19]. Open access funding provided by University of Helsinki.

Conflicts of Interest: The authors report no conflict of interest.

\section{References}

1. Cao, C.; Tian, D.; Park, J.; Allan, J.; Pataky, K.; Yan, T. A systematic review and meta-analysis of surgical treatments for malignant pleural mesothelioma. Lung Cancer 2014, 83, 240-245. [CrossRef] [PubMed]

2. Carbone, M.; Kratzke, R.A.; Testa, J.R. The pathogenesis of mesothelioma. Semin. Oncol. 2002, 29, 2-17. [CrossRef] [PubMed]

3. Robinson, B.W.S.; Lake, R.A. Advances in Malignant Mesothelioma. N. Engl. J. Med. 2005, 353, 1591-1603. [CrossRef] [PubMed]

4. Robinson, B.M. Malignant pleural mesothelioma: An epidemiological perspective. Ann. Cardiothorac. Surg. 2012, 1, 491-496. [CrossRef] [PubMed] 
5. Rusch, V.W. Extrapleural pneumonectomy and extended pleurectomy/decortication for malignant pleural mesothelioma: The Memorial Sloan-Kettering Cancer Center approach. Ann. Cardiothorac. Surg. 2012, 1, 523-531. [CrossRef]

6. Rusch, V.W. A phase II study of intrapleural immunochemotherapy, pleurectomy/decortication, radiotherapy, systemic chemotherapy, and long-term subcutaneous IL-2 in stage II-III malignant pleural mesothelioma. Eur. J. Cardio-Thoracic Surg. 2007, 31, 534-535. [CrossRef]

7. Tilleman, T.R.; Richards, W.G.; Zellos, L.; Johnson, B.E.; Jaklitsch, M.T.; Mueller, J.; Yeap, B.Y.; Mujoomdar, A.A.; Ducko, C.T.; Bueno, R.; et al. Extrapleural pneumonectomy followed by intracavitary intraoperative hyperthermic cisplatin with pharmacologic cytoprotection for treatment of malignant pleural mesothelioma: A phase II prospective study. J. Thorac. Cardiovasc. Surg. 2009, 138, 405-411. [CrossRef]

8. Wolf, A.S.; Daniel, J.; Sugarbaker, D.J. Surgical Techniques for Multimodality Treatment of Malignant Pleural Mesothelioma: Extrapleural Pneumonectomy and Pleurectomy/Decortication. Semin. Thorac. Cardiovasc. Surg. 2009, 21, 132-148. [CrossRef]

9. Jänne, P.A.; Baldini, E.H. Patterns of failure following surgical resection for malignant pleural mesothelioma. Thorac. Surg. Clin. 2004, 14, 567-573. [CrossRef]

10. Zellos, L.; Richards, W.G.; Capalbo, L.; Jaklitsch, M.T.; Chirieac, L.R.; Johnson, B.E.; Bueno, R.; Sugarbaker, D.J. A phase I study of extrapleural pneumonectomy and intracavitary intraoperative hyperthermic cisplatin with amifostine cytoprotection for malignant pleural mesothelioma. J. Thorac. Cardiovasc. Surg. 2009, 137, 453-458. [CrossRef]

11. Sugarbaker, P.H.; Stuart, O.A.; Eger, C. Pharmacokinetics of Hyperthermic Intrathoracic Chemotherapy following Pleurectomy and Decortication. Gastroenterol. Res. Pr. 2012, 2012, 1-4. [CrossRef]

12. Ambrogi, M.C.; Bertoglio, P.; Aprile, V.; Chella, A.; Korasidis, S.; Fontanini, G.; Fanucchi, O.; Lucchi, M.; Mussi, A. Diaphragm and lung-preserving surgery with hyperthermic chemotherapy for malignant pleural mesothelioma: A 10-year experience. J. Thorac. Cardiovasc. Surg. 2018, 155, 1857-1866.e2. [CrossRef]

13. Bertoglio, P.; Aprile, V.; Ambrogi, M.C.; Mussi, A.; Lucchi, M. The role of intracavitary therapies in the treatment of malignant pleural mesothelioma. J. Thorac. Dis. 2018, 10, S293-S297. [CrossRef] [PubMed]

14. Matsuzaki, Y.; Edagawa, M.; Shimizu, T.; Hara, M.; Tomita, M.; Ayabe, T.; Onitsuka, T. Intrapleural Hyperthermic Perfusion With Chemotherapy Increases Apoptosis in Malignant Pleuritis. Ann. Thorac. Surg. 2004, 78, 1769-1772. [CrossRef] [PubMed]

15. González-Moreno, S.; González-Bayón, L.A.; Ortega-Pérez, G. Hyperthermic intraperitoneal chemotherapy: Rationale and technique. World J. Gastrointest. Oncol. 2010, 2, 68-75. [CrossRef] [PubMed]

16. Passot, G.; Vaudoyer, D.; Villeneuve, L.; Kepenekian, V.; Beaujard, A.-C.; Bakrin, N.; Cotte, E.; Gilly, F.-N.; Glehen, O. What made hyperthermic intraperitoneal chemotherapy an effective curative treatment for peritoneal surface malignancy: A 25-year experience with 1,125 procedures. J. Surg. Oncol. 2016, 113, 796-803. [CrossRef]

17. Egger, M.; Smith, G.D.; Schneider, M.; Minder, C. Bias in meta-analysis detected by a simple, graphical test. BMJ 1997, 315, 629-634. [CrossRef]

18. Richards, W.G.; Zellos, L.; Bueno, R.; Jaklitsch, M.T.; Jänne, P.A.; Chirieac, L.R.; Yeap, B.Y.; Dekkers, R.J.; Hartigan, P.M.; Capalbo, L.; et al. Phase I to II Study of Pleurectomy/Decortication and Intraoperative Intracavitary Hyperthermic Cisplatin Lavage for Mesothelioma. J. Clin. Oncol. 2006, 24, 1561-1567. [CrossRef] [PubMed]

19. Hod, T.; Freedberg, K.J.; Motwani, S.S.; Chen, M.; Frendl, G.; Leaf, D.; Gupta, S.; Mothi, S.S.; Richards, W.G.; Bueno, R.; et al. Acute kidney injury after cytoreductive surgery and hyperthermic intraoperative cisplatin chemotherapy for malignant pleural mesothelioma. J. Thorac. Cardiovasc. Surg. 2021, 161, 1510-1518. [CrossRef]

20. Sugarbaker, D.J.; Gill, R.R.; Yeap, B.Y.; Wolf, A.S.; DaSilva, M.C.; Baldini, E.H.; Bueno, R.; Richards, W.G. Hyperthermic intraoperative pleural cisplatin chemotherapy extends interval to recurrence and survival among low-risk patients with malignant pleural mesothelioma undergoing surgical macroscopic complete resection. J. Thorac. Cardiovasc. Surg. 2013, 145, 955-963. [CrossRef]

21. Burt, B.M.; Richards, W.G.; Lee, H.-S.; Bartel, S.; Dasilva, M.C.; Gill, R.R.; Jaklitsch, M.T.; Johnson, B.E.; Swanson, S.J.; Bueno, R.; et al. A Phase I Trial of Surgical Resection and Intraoperative Hyperthermic Cisplatin and Gemcitabine for Pleural Mesothelioma. J. Thorac. Oncol. 2018, 13, 1400-1409. [CrossRef]

22. Migliore, M.; Calvo, D.; Criscione, A.; Palmucci, S.; Sanzà, G.F.; Caltabiano, R.; Spatola, C.; Privitera, G.; Aiello, M.M.; Parra, H.S.; et al. Pleurectomy/decortication and hyperthermic intrapleural chemotherapy for malignant pleural mesothelioma: Initial experience. Futur. Oncol. 2015, 11, 19-22. [CrossRef] [PubMed]

23. Van Sandick, J.W.; Kappers, I.; Baas, P.; Haas, R.L.; Klomp, H.M. Surgical Treatment in the Management of Malignant Pleural Mesothelioma: A Single Institution's Experience. Ann. Surg. Oncol. 2008, 15, 1757-1764. [CrossRef] [PubMed]

24. Klotz, L.V.; Lindner, M.; Eichhorn, M.E.; Grützner, U.; Koch, I.; Winter, H.; Kauke, T.; Duell, T.; Hatz, R.A. Pleurectomy/decortication and hyperthermic intrathoracic chemoperfusion using cisplatin and doxorubicin for malignant pleural mesothelioma. J. Thorac. Dis. 2019, 11, 1963-1972. [CrossRef] [PubMed]

25. Cohen, J. Statistical Power Analysis for the Behavioral Sciences, 2nd ed.; Lawrence Erlbaum Associates: Hillsdale, NJ, USA, 1988; p. 567.

26. Lang-Lazdunski, L.; Bille, A.; Lal, R.; Cane, P.; McLean, E.; Landau, D.; Steele, J.; Spicer, J. Pleurectomy/Decortication is Superior to Extrapleural Pneumonectomy in the Multimodality Management of Patients with Malignant Pleural Mesothelioma. J. Thorac. Oncol. 2012, 7, 737-743. [CrossRef] 
27. Friedberg, J.S.; Simone, C.; Culligan, M.J.; Barsky, A.R.; Doucette, A.; McNulty, S.; Hahn, S.M.; Alley, E.; Sterman, D.; Glatstein, E.; et al. Extended Pleurectomy-Decortication-Based Treatment for Advanced Stage Epithelial Mesothelioma Yielding a Median Survival of Nearly Three Years. Ann. Thorac. Surg. 2017, 103, 912-919. [CrossRef]

28. Lucchi, M.; Chella, A.; Melfi, F.; Dini, P.; Ambrogi, M.; Fino, L.; Fontanini, G.; Mussi, A. A phase II study of intrapleural immuno-chemotherapy, pleurectomy/decortication, radiotherapy, systemic chemotherapy and long-term sub-cutaneous IL-2 in stage II-III malignant pleural mesothelioma. Eur. J. Cardio-Thoracic Surg. 2007, 31, 529-534. [CrossRef]

29. Kindler, H.L.; Ismaila, N.; Armato, S.G.; Bueno, R.; Hesdorffer, M.; Jahan, T.; Jones, C.M.; Miettinen, M.; Pass, H.; Rimner, A.; et al. Treatment of Malignant Pleural Mesothelioma: American Society of Clinical Oncology Clinical Practice Guideline. J. Clin. Oncol. 2018, 36, 1343-1373. [CrossRef]

30. Christophi, C.; Winkworth, A.; Muralihdaran, V.; Evans, P. The treatment of malignancy by hyperthermia. Surg. Oncol. 1998, 7, 83-90. [CrossRef]

31. Sugarbaker, P.H. Laboratory and clinical basis for hyperthermia as a component of intracavitary chemotherapy. Int. J. Hyperth. 2007, 23, 431-442. [CrossRef]

32. Gill, R.S.; Al-Adra, D.P.; Nagendran, J.; Campbell, S.; Shi, X.; Haase, E.; Schiller, D. Treatment of gastric cancer with peritoneal carcinomatosis by cytoreductive surgery and HIPEC: A systematic review of survival, mortality, and morbidity. J. Surg. Oncol. 2011, 104, 692-698. [CrossRef]

33. Roh, S.J.; Park, S.C.; Choi, J.; Lee, J.S.; Lee, D.W.; Hong, C.W.; Han, K.S.; Park, H.C.; Sohn, D.K.; Oh, J.H. Cytoreductive Surgery and Hyperthermic Intraperitoneal Chemotherapy With Mitomycin C Used for Colorectal Peritoneal Carcinomatosis. Ann. Coloproctology 2020, 36, 22-29. [CrossRef]

34. Vallicelli, C.; Cavaliere, D.; Catena, F.; Coccolini, F.; Ansaloni, L.; Poiasina, E.; Abongwa, H.K.; De Simone, B.; Alberici, L.; Framarini, M.; et al. Management of peritoneal carcinomatosis from colorectal cancer: Review of the literature. Int. J. Color. Dis. 2014, 29, 895-898. [CrossRef]

35. El Halabi, H.; Gushchin, V.; Francis, J.; Athas, N.; Macdonald, R.; Nieroda, C.; Studeman, K.; Sardi, A. The Role of Cytoreductive Surgery and Heated Intraperitoneal Chemotherapy (CRS/HIPEC) in Patients with High-Grade Appendiceal Carcinoma and Extensive Peritoneal Carcinomatosis. Ann. Surg. Oncol. 2011, 19, 110-114. [CrossRef]

36. Spiliotis, J.; Halkia, E.; Lianos, E.; Kalantzi, N.; Grivas, A.; Efstathiou, E.; Giassas, S. Cytoreductive Surgery and HIPEC in Recurrent Epithelial Ovarian Cancer: A Prospective Randomized Phase III Study. Ann. Surg. Oncol. 2015, 22, 1570-1575. [CrossRef] [PubMed]

37. Zhao, Z.-Y.; Zhao, S.-S.; Ren, M.; Liu, Z.-L.; Li, Z.; Yang, L. Effect of hyperthermic intrathoracic chemotherapy on the malignant pleural mesothelioma: A systematic review and meta-analysis. Oncotarget 2017, 8, 100640-100647. [CrossRef]

38. Işık, A.F.; Şanlı, M.; Yılmaz, M.; Meteroğlu, F.; Dikensoy, Ö.; Sevinç, A.; Camcı, C.; Tunçözgür, B.; Elbeyli, L. Intrapleural hyperthermic perfusion chemotherapy in subjects with metastatic pleural malignancies. Respir. Med. 2013, 107, 762-767. [CrossRef] [PubMed]

39. Ceresoli, G.L.; Locati, L.D.; Ferreri, A.J.M.; Cozzarini, C.; Passoni, P.; Melloni, G.; Zannini, P.; Bolognesi, A.; Villa, E. Therapeutic outcome according to histologic subtype in 121 patients with malignant pleural mesothelioma. Lung Cancer 2001, 34, $279-287$. [CrossRef]

40. Verma, V.; Ahern, C.A.; Berlind, C.G.; Lindsay, W.D.; Shabason, J.; Sharma, S.; Culligan, M.J.; Grover, S.; Friedberg, J.S.; Simone, C.B. Survival by Histologic Subtype of Malignant Pleural Mesothelioma and the Impact of Surgical Resection on Overall Survival. Clin. Lung Cancer 2018, 19, e901-e912. [CrossRef] [PubMed]

41. Liu, L.; Zhang, N.; Min, J.; Su, H.; Wang, H.; Chen, D.; Sun, L.; Zhang, H.; Li, W.; Zhang, H. Retrospective analysis on the safety of 5,759 times of bedside hyperthermic intra-peritoneal or intra-pleural chemotherapy (HIPEC). Oncotarget 2016, 7, 21570-21578. [CrossRef] [PubMed] 